\title{
Diagnostic Value of Hematological Parameters in Pelvic Inflammatory Disease
}

\author{
Pelvik Enflamatuvar Hastalıkta Hematolojik Parametrelerin Tanısal Değeri
}

\author{
(D) Sevinj Aliyeva1, (D) Serdar Kaya², (D) Zeynep Soyman1, (D) Güler Ateșer1, (D) Haluk Bacanakgil1, (D) Birtan Boran1 \\ 1istanbul Training and Research Hospital, Clinic of Obstetrics and Gynecology, İstanbul, Turkey \\ 2Akdeniz University Faculty of Medicine,Department of Obstetrics and Gynecology, Antalya, Turkey
}

\begin{abstract}
Introduction: In this study, we aimed to investigate the diagnostic value of hematologic parameters in pelvic inflammatory disease (PID).

Methods: In this retrospective study, 122 patients diagnosed as PID (patient group) and 150 healthy women (control group) who applied for routine gynecological examination between May 2010 and May 2016 were included. White blood cell (WBC), neutrophil count, lymphocyte count, mean platelet volume (MPV), platelet/lymphocyte ratio (PLR), neutrophil/lymphocyte ratio (NLR), platelet distribution volume (PDW), plateletcrit (PCT) values of the patient and control groups were compared. Results: There was no difference in terms of age, platelet, MPV, PCT, PDW values between the patient and control groups $(p>0.05)$. NLR and PLR values were significantly higher in the patient group compared to the control group $(p<0.001)$. While NLR showed a significant positive correlation with C-reactive protein (CRP) and WBC count, PLR was found to have a positive correlation only with CRP. In the diagnosis of PID, the sensitivity of NLR was similar to the increase in WBC count, but its specificity was higher. The sensitivity $(80.3 \%)$ and specificity (78.7\%) of NLR were close to neutrophil count, which is an important inflammatory marker, and it was the second most valuable marker after neutrophil count in the diagnosis of PID. Conclusion: It was concluded that NLR, which is one of the complete blood count parameters, has sensitivity and specificity higher than white cell count and close to neutrophil count in PID diagnosis, and is a valuable inflammatory marker in PID diagnosis.
\end{abstract}

Keywords: Pelvic inflammatory disease, hematologic parameters, inflammatory marker

\section{öz}

Amaç: $\mathrm{Bu}$ çalışmada hematolojik parametrelerin pelvik enflamatuvar hastalıktaki (PiH) tanısal değerini incelemeyi amaçladık.

Yöntemler: Bu retrospektif çalışmaya Mayıs 2010 ve Mayıs 2016 tarihleri arasında PiH tanısı alan 122 hasta ile kontrol grubu olarak rutin jinekolojik muayene için başvuran 150 sağlıkıı kadın dahil edildi. Çalıșma ve kontrol gruplarının beyaz küre (WBC), nötrofil, lenfosit, ortalama platelet hacmi (MPV), platelet/lenfosit oranı (PLR), nötrofil/lenfosit oranı (NLR), platelet dağılım hacmi (PDW), plateletkrit (PCT) değerleri karşılaştırıldı.

Bulgular: Çalışma ve kontrol grupları karşılaştırıldığında yaş, platelet, MPV, PCT, PDW değerleri açısından fark saptanmadı $(p>0,05)$. NLR ve PLR değerleri kontrol grubuna göre hasta grubunda anlamlı yüksek saptandı $(p<0,001)$. NLR, CRP ve WBC sayımı ile pozitif yönde anlamlı korelasyon gösterirken, PLR'nin yalnızca C-reaktif proteini (CRP) ile pozitif yönde anlamlı korelasyon gösterdiği saptandı. PIH tanısında NLR'nin sensitivitesinin WBC artışı ile benzer, spesifitesinin ise daha yüksek olduğu saptandı. NLR'nin sensitivite $(\% 80,3)$ ve spesifitesinin $(\% 78,7)$ önemli bir enflamatuvar belirteç olan nötrofil sayımına yakın olduğu ve PiH tanısında hemogram parametreleri arasında nötrofil sayımından sonra en değerli ikinci belirteç olduğu saptandı.

Sonuç: Hemogram parametrelerinden NLR'nin PiH tanısında WBC sayımından daha yüksek ve nötrofil sayımına yakın sensitivite ve spesifiteye sahip olduğu ve PiH tanısında değerli bir enflamatuvar belirteç olduğu sonucuna varılmıştır.

Anahtar Kelimeler: Pelvik enflamatuvar hastalık, hematolojik parametreler, enflamatuvar belirteç 


\section{Introduction}

Pelvic inflammatory disease (PID) is a common infection of women of reproductive age. It is an ascending polymicrobial infection caused by microorganisms colonizing in the endocervix and causing inflammation of the upper genital system. Infection extending to the endometrium and fallopian tubes may affect neighboring pelvic tissues and cause clinical conditions such as endometritis, pelvic peritonitis, tubo-ovarian abscess and salpingitis. The PID clinic may vary from mild symptoms and signs to severe lower abdominal pain, and mild clinical findings may cause difficulty in diagnosis (1-3). There are studies where changes in hematological parameters such as neutrophil/lymphocyte ratio (NLR), platelet/lymphocyte ratio (PLR), mean platelet volume (MPV), plateletcrit (PCT) in various malignant and benign diseases such as coronary artery disease, inflammatory diseases, preeclampsia, gynecologic and gastrointestinal cancers have been evaluated as inflammatory markers with prognostic and predictive value $(4,5)$.

In this study, we aimed to evaluate hematological parameters as inflammatory markers in PID.

\section{Methods}

In this study, 122 patients admitted to our gynecology and obstetrics clinic between May 2010 and May 2016 and diagnosed as PID were included in the patient group, and 150 patients who did not have active complaints but who applied to our gynecology outpatient clinic for routine gynecological examination were included in the control group. The files of the patients were retrospectively reviewed and patients diagnosed as PID according to the Sexually Transmitted Disease Guidelines (2) of the Center for Disease Control and Prevention were included in the study. Specificity increasing criteria such as presence of tenderness in uterine, adnexal or cervical movements and associated fever $>38.3^{\circ} \mathrm{C}$ in patients with acute onset pelvic or lower abdominal pain, increased cervical mucopurulent discharge, increased erythrocyte sedimentation rate or C-reactive protein (CRP) levels were used to diagnose PID. Patients with chronic disease, existing additional focus of infection and malignancy were excluded from the study. In addition, patients with use of non-steroidal anti-inflammatory drugs, antibiotics, oral anticoagulants, and oral contraceptives that could affect the parameters evaluated were excluded. Pre-treatment hemoglobin, hematocrit, white blood cell (WBC) count, platelet, MPV, PCT, platelet distribution width (PDW), CRP values of the subjects included in the patient group were recorded and PLR and NLR were calculated. Patient and control groups were compared in terms of parameters.

Ethics committee approval was obtained for the study (İstanbul Training and Research Hospital Ethics Committee (decision no: 914, date: 06.01.2017). Informed verbal and written informed consent was obtained from.

\section{Statistical Analysis}

SPSS 15.0 for Windows program was used for statistical analysis. Regarding descriptive statistics, mean, standard deviation, minimum and maximum were used for numerical variables, and numbers and percentages were used for categorical variables. Comparisons of numerical variables were made by using Student's t-test when normal distribution was met and by using Mann-Whitney $U$ test when normal distribution was not met in the comparison of two independent groups. The relationship between numerical variables was examined by Spearman correlation analysis since no parametric test condition was provided. Statistical significance level was accepted as $p<0.05$.

\section{Results}

Demographic characteristics and hematological parameters of the groups are shown in Table 1. There was no significant difference between the groups in terms of mean maternal age $(p=0.700)$, while the mean parity was significantly lower in the patient group $(p<0.001)$.

\section{Table 1. Comparison of demographic characteristics and complete blood count parameters of patient and control groups}

\begin{tabular}{|c|c|c|c|c|c|c|c|}
\hline & \multicolumn{3}{|c|}{ Patient group $(n=122)$} & \multicolumn{3}{|c|}{ Control group $(n=150)$} & \multirow[b]{2}{*}{ p } \\
\hline & Mean \pm SD & Min-Max & Median & Mean \pm SD & Min-Max & Median & \\
\hline Age & $36.4 \pm 9.1$ & $18-80$ & 36.5 & $36.9 \pm 4.4$ & $19-45$ & 37.5 & 0.700 \\
\hline Parity & $2.0 \pm 1.4$ & $0-7$ & 2 & $2.7 \pm 1.5$ & $0-7$ & 3 & $<0.001$ \\
\hline Hemoglobin & $11.7 \pm 1.8$ & 7.5-15 & 12 & $12.7 \pm 1.5$ & 7.9-15.9 & 12.9 & $<0.001$ \\
\hline Hematocrit & $35.9 \pm 4.8$ & $23.4-45.4$ & 36.2 & $38.2 \pm 4.1$ & $25.3-50.2$ & 38.7 & $<0.001$ \\
\hline WBC & $12.9 \pm 5.4$ & $4.9-28$ & 11.74 & $7.6 \pm 2.2$ & $3.6-14.7$ & 7.3 & $<0.001$ \\
\hline PLT & $305.4 \pm 110.8$ & $62-728$ & 281 & $281.3 \pm 71.6$ & $2.7-478$ & 279 & 0.345 \\
\hline MPV & $8.97 \pm 1.33$ & $5.8-13.4$ & 9.1 & $9.28 \pm 1.42$ & $2.3-12.4$ & 9.3 & 0.066 \\
\hline PCT & $0.32 \pm 0.39$ & $0.1-3.63$ & 0.26 & $0.27 \pm 0.09$ & $0.1-1.1$ & 0.3 & 0.799 \\
\hline Neutrophil & $9.9 \pm 5.3$ & $2.4-25.5$ & 8.195 & $4.7 \pm 1.8$ & $1.9-12$ & 4.3 & $<0.001$ \\
\hline Lymphocyte & $1.9 \pm 0.8$ & $0.3-4.4$ & 1.8 & $2.3 \pm 0.7$ & $0.5-4.3$ & 2.3 & $<0.001$ \\
\hline PLR & $199.4 \pm 123.4$ & $35.4-762.8$ & 167.8 & $131.9 \pm 51.2$ & $1.8-371.2$ & 120.4 & $<0.001$ \\
\hline NLR & $6.99 \pm 6.29$ & $1.19-38.07$ & 4.46 & $2.25 \pm 1.84$ & $0.78-20.98$ & 1.92 & $<0.001$ \\
\hline PDW & $25.5 \pm 17.4$ & $10.3-73.4$ & 16.2 & $24.1 \pm 16.2$ & $11-64.1$ & 16.2 & 0.326 \\
\hline CRP & $13.6 \pm 19.2$ & $0.1-96.1$ & 7.8 & - & - & - & - \\
\hline
\end{tabular}


When the treatment methods were examined, it was seen that $77 \%$ of the patient group received medical treatment and $23 \%$ received surgical treatment. Compared with the control group, lymphocyte, hemoglobin and hematocrit values were significantly lower in the patient group $(p<0.001)$, whereas neutrophil and WBC counts were significantly higher in the patient group $(p<0.001)$. PLR and NLR were significantly higher in the patient group $(p<0.001)$. There was no significant difference between patient and control groups in terms of platelet count, MPV, PCT and PDW values $(p>0.05)$.

The correlation analyses of CRP and WBC values and other hematological parameters of the subjects in the patient group are shown in Table 2. While there was a significant positive correlation between NLR and PLR values and CRP values $(r=0.398, p<0.001$ and $r=0.282, p=0.002$, respectively), there was a significant negative correlation between MPV and CRP values $(r=-0,185, p=0.041)$. There was no significant correlation between PCT and PDW values and CRP values ( $p>0.05)$. While there was a significant positive correlation between NLR and WBC values $(r=0.593$, $p<0.001$ ), there was no significant correlation between PCT, MPV, PDW and PLR values and WBC values ( $p>0.05)$.

In receiver operator characteristic analysis, sensitivity and specificity of neutrophil count in the diagnosis of PID were found to be $82 \%$ with a cut-off value of 5.63 , and sensitivity was $80.3 \%$ and specificity was $78.3 \%$ for a cut-off value of 2.58 for NLR. When the cut-off value for WBC count

\begin{tabular}{|c|c|c|c|c|}
\hline & \multicolumn{2}{|c|}{$\operatorname{CRP}(n=122)$} & \multicolumn{2}{|c|}{ WBC $(n=122)$} \\
\hline & Rho & $p$ & Rho & $p$ \\
\hline WBC & $0.270^{*}$ & 0.003 & - & - \\
\hline PCT & 0.047 & 0.607 & 0.146 & 0.108 \\
\hline NLR & $0.398 * *$ & $<0.001$ & $0.593 * *$ & $<0.001$ \\
\hline PLR & $0.282^{*}$ & 0.002 & 0.048 & 0.601 \\
\hline MPV & $-0.185^{*}$ & 0.041 & -0.094 & 0.304 \\
\hline PDW & -0.037 & 0.686 & 0.100 & 0.274 \\
\hline
\end{tabular}

CRP: C-reactive protein, WBC: white cell count, PCT: plateletcrit, NLR: neutrophil/ lymphocyte ratio, PLR: platelet/lymphocyte ratio, MPV: mean platelet volume, PDW platelet distribution volume, Rho: Spearman's $r,{ }^{*}: p<0.05,{ }^{* *}: p<0.001$ was taken as 8.42 , its sensitivity and specificity were $80.3 \%$ and $70.4 \%$, respectively (Table 3).

\section{Discussion}

In this retrospective study, we investigated whether NLR, PLR, MPV, and PDW could be used as a diagnostic marker in PID. Our hypothesis in this study was that these parameters might be diagnostic markers such as CRP and increased WBC count used in the diagnosis of PID. In accordance with our hypothesis, in our study, NLR and PLR values were found to be higher in patients with PID compared to the control group. As a result of this study, these parameters were found to have an important role in the diagnosis of PID as inflammatory markers. In addition, the sensitivity and specificity of NLR in the diagnosis was found to be high As a result of our study, the sensitivity of NLR was similar to the increase in WBC count and the specificity was higher in the diagnosis of PID. The sensitivity and specificity of NLR was found to be close to neutrophil count, which is an important inflammatory marker, and was the second most valuable marker in the diagnosis of PID after neutrophil count.

PID is an inflammatory disorder of the female upper genital system and includes different clinical features such as endometritis, salpingitis, tubo-ovarian abscess and pelvic peritonitis. The clinical diagnosis is 65$90 \%$, even in the most experienced hands $(2,6)$. Early diagnosis not only reduces the risk of infection spread but also reduces the complication rates. Although laparoscopy is the gold standard for diagnosis, it is a costly and invasive procedure that limits its use. Although the diagnosis of PID is mainly made clinically, laboratory tests are used as auxiliary diagnostic tools. Since clinical findings are non-specific and obscure in many cases, laboratory tests play an important role in supporting the diagnosis $(2,3)$. In the meta-analysis of the diagnostic value of the markers used in the diagnosis of PID, Kahn et al. (7) concluded that there was no biomarker that could be used alone or in combination in the diagnosis of PID. In 10 of the 12 studies examined in this metaanalysis, laparoscopy was considered the gold standard in diagnosis, while the sensitivity of CRP was reported to be $74-93 \%$ and the sensitivity of sedimentation was reported to be $64-81 \%$. CRP begins to increase 48 hours after the onset of symptoms. Increased CRP and sedimentation may also be associated with non-inflammatory factors such as age, anemia, gender, and renal failure (8). Therefore, the use of these two

Table 3. Diagnostic values of complete blood count parameters in pelvic inflammatory disease

\begin{tabular}{|l|l|l|l|l|l|l|}
\hline & AUC & Cut-off & Sensitivity & Specificity & PPV & NPV \\
\hline NLR & 0.864 & 2.58 & 80.3 & 78.7 & 75.4 & 83.1 \\
\hline Neutrophil & 0.863 & 5.63 & 82.0 & 82.0 & 78.7 & 84.8 \\
\hline WBC & 0.827 & 8.42 & 80.3 & 70.4 & 71.5 & 82.2 \\
\hline PLR & 0.679 & 127 & 68.0 & 60.0 & 58.0 & 69.8 \\
\hline Lymphocyte & 0.330 & 2.11 & 66.4 & 61.3 & 58.3 & 69.2 \\
\hline MPV & 0.421 & 9.35 & 61.5 & 49.3 & 50.0 & 61.5 \\
\hline PCT & 0.509 & 0.252 & 52.5 & 47.3 & 44.8 & 55.0 \\
\hline PLT & 0.533 & 279.5 & 50.8 & 50.7 & 45.6 & 55.9 \\
\hline PDW & 0.465 & 16.1 & 50.8 & 47.3 & 44.0 & 54.2 \\
\hline
\end{tabular}

AUC: area under the curve, PPV: positive predictive value, NPV: negative predictive value, NLR: neutrophil/lymphocyte ratio, WBC: white cell count, PLR: platelet/lymphocyte ratio, MPV: mean platelet volume, PCT: plateletcrit, PLT: platelet, PDW: platelet distribution width 
parameters in diagnosis is limited. This necessitates the evaluation of additional inflammatory markers in the diagnosis of PID.

As a result of neutrophil activation caused by tissue destruction, the release of enzymes such as myeloperoxidase, acid phosphatase and elastase increases and neutrophil dominance is observed and thus NLR increases. In recent studies, NLR has been evaluated as an inflammatory marker (9-12). AKopuz et al. (10) reported that NLR values were significantly higher in patients diagnosed with PID compared to the control group before treatment, and in these patients they found that clinical improvement and NLR regressed to normal levels after treatment. They concluded that NLR could be used as a marker of clinical improvement in PID. In a study investigating the diagnostic value of complete blood count (CBC) parameters and CRP in PID cases, Seçkin et al. (11) found that NLR had the highest sensitivity and specificity in the diagnosis of PID and had similar sensitivity and specificity to CRP. They concluded that NLR could be used together with other CBC parameters in the diagnosis of PID.

Consistent with the literature, in our study, NLR was significantly higher in the PID group than in the control group $(p<0.001)$. It was observed that NLR had the second highest sensitivity (80.3\%) and specificity (78.7\%) after neutrophil count among all CBC parameters. Thus, we found that NLR has higher sensitivity and specificity in the diagnosis of PID compared to WBC, and PDW, PLR and MPV, which are examined as inflammatory markers in recent studies, and consequently that NLR is a valuable inflammatory marker that can be used in the diagnosis of PID, such as CRP. Compared with similar studies in the literature, the high number of cases may be considered as the superior aspect of our study.

PLR has been shown to increase significantly in many inflammatory diseases (11,13-15). Consistent with the literature, in our study, PLR was found to be significantly higher in patients with PID, whereas sensitivity (68\%) and specificity (60\%) of PLR were lower than NLR and WBC, and higher than MPV and PDW.

MPV, which is a marker of function and activation of platelets, is altered by platelet activation $(12,13)$. MPV has been shown to decrease in inflammatory diseases such as rheumatoid arthritis and inflammatory bowel disease in recent studies $(16,17)$. In the study of Incebiyik et al. (12), MPV was significantly lower in patients with PID and MPV was a more valuable marker in the diagnosis of PID than leukocyte count. Although Seçkin et al. (11) found that MPV was significantly lower in patients with PID; they suggested that MPV was not a valuable marker in the diagnosis of PID (11). Contrary to these studies, no statistically significant difference was found between patient and control groups for MPV. In the diagnosis of PID, sensitivity (61.5\%) and specificity (49.3) of MPV were lower than NLR and PLR. While PDW values were not different between the patient and control groups, the sensitivity (50.8\%) and specificity (47.3\%) of PDW were not considered as a valuable marker in the diagnosis of PID.

Retrospective design of the study, lack of CRP values in the control group and the effect of treatment on the parameters examined were the main limitations of our study. In addition, the fact that the presence of pelvic abscess, an important complication of PID, on the studied parameters has not been investigated is another limitation of our study.

\section{Conclusion}

It was found that NLR was more specific and sensitive than MPV, PDW, PLR parameters in the diagnosis of PID. In addition, it was concluded that NLR, which has a higher sensitivity and specificity than WBC count and similar sensitivity and specificity to neutrophil count, has an important role in the diagnosis of PID. Further studies are needed on this subject.

Ethics Committee Approval: Ethics committee approval was obtained for the study (Istanbul Training and Research Hospital Ethics Committee (decision no: 914, date: 06.01.2017).

Informed Consent: Informed verbal and written informed consent was obtained from.

Peer-review: Externally peer-reviewed.

Author Contributions: Surgical and Medical Practices - S.A., S.K., Z.S., G.A., H.B., B.B.; Concept - S.A., S.K., Z.S., H.B., B.B.; Design - S.A., S.K., G.A., H.B., B.B.; Data Collection and/or Processing - S.A., S.K, Z.S.; Analysis and/or Interpretation - S.A., S.K., Z.S., G.A.; Literature Search - S.A., S.K. G.A.; Writing Manuscript - S.A., S.K., Z.S., B.B.

Conflict of Interest: No conflict of interest was declared by the authors.

Financial Disclosure: The authors declared that this study received no financial support.

\section{References}

1. Caroline Mitchell, Malavika Prabhu. Pelvik inflammatory disease: Current concepts in pathogenesis, diagnosis and treatment. Infect Dis Clin North Am 2013; 27: 793-809.

2. Workowski KA, Berman S. Centers for disease control and prevention (CDC). Sexually transmitted diseases treatment guidelines 2010; 59:1-110.

3. Sweet RL. Pelvic inflammatory disease: current concepts of diagnosis and management. Curr Infect Dis Rep 2012

4. Zhang WW, Liu KJ, Hu GL, Liang WJ. Preoperative platelet/lymphocyte ratio is a superior prognostic factor compared to other systemic inflammatory response markers in ovarian cancer patients. Tumour Biol 2015; 36: 8831-7.

5. Bellos I, Fitrou G, Pergialiotis V, Papantoniou N, Daskalakis G. Mean platelet volume values in preeclampsia: A systematic review and meta-analysis. Pregnancy Hypertens 2018; 13: 174-180.

6. Chappell CA, Wiesenfeld HC. Pathogenesis, diagnosis, and management of severe pelvic inflammatory disease and tuboovarian abscess. Clin Obstet Gynecol 2012; 55: 893-903.

7. Kahn JG, Walker CK, Washington AE, Landers DV, Sweet RL. Diagnosing pelvic inflammatory disease. A comprehensive analysis and considerations for developing a new model. JAMA 1991; 266: 2594-604.

8. Clyne B, Olshaker JS. The C-reactive protein. J Emerg Med 1999; 17: 1019-25.

9. Güneş M, Umul M, Altok M, Akyuz M, İşoğlu CS, Uruc F, et al. Predictive role of hematologic parameters in testicular torsion. Korean J Urol 2015; 56: 324-9.

10. Akopuz A, Turan V, Ozcan A, Kopuz Y, Toz E, Kurt S. A novel marker for the assessment of the treatment result in pelvic inflammatory disease. Minerva Ginecol 2016; 68: 117-23.

11. Seçkin KD, Karslı MF, Yücel B, Özköse B, Yıldırım D, Çetin BA, et al. Neutrophil lymphocyte ratio, platelet lymphocyte ratio and mean platelet volume; which one is more predictive in the diagnosis of pelvic inflammatory disease? Gynecol Obstet Reprod Med 2015; 21: 150-4. 
12. Incebiyik A, Seker A, Vural M, Gul Hilali N, Camuzcuoglu A, Camuzcuoglu H. May mean platelet volume levels be a predictor in the diagnosis of pelvic inflammatory disease? Wien Klin Wochenschr 2014; 126: 422-6.

13. Kim MA, Han GH, Kwon JY, Kim YH. Clinical significance of platelet-tolymphocyte ratio in women with preeclampsia. Am J Reprod Immunol 2018; 80: e12973.

14. Özer S, Yılmaz R, Sönmezgöz E, Karaaslan E, Tașkın S, Bütün I, et al. Simple markers for subclinical inflammation in patients with Familial Mediterranean Fever. Med Sci Monit 2015; 21: 298-303.
15. Boyraz I, Koç B, Boyacı A, Tutoğlu A, Sarman H, Ozkan H. Ratio of neutrophil/ lymphocyte and platelet/lymphocyte in patient with ankylosing spondylitis that are treating with anti-TNF. Int J Clin Exp Med 2014; 15: 2912-5.

16. Kisacik B, Tufan A, Kalyoncu U, Karadag O, Akdogan A, Ozturk MA, et al. Mean platelet volume (MPV) as an inflammatory marker in ankylosing spondylitis and rheumatoid arthritis. Joint Bone Spine 2008; 75: 291-4.

17. Yüksel O, Helvaci K, Başar O, Köklü S, Caner S, Helvaci N, et al. An overlooked indicator of disease activity in ulcerative colitis: mean platelet volume. Platelets 2009; 20: 277-81. 